\title{
(1)(2) \\ An Agenda for Decolonising Law in Africa: Conceptualising the Curriculum
}

Asikia Karibi-Whyte ${ }^{1}$ - University of Lagos

\section{Abstract}

Journal of Decolonising Disciplines

Volume 2, Issue 1 (2020)

eISSN: 2664-3405

DOI: https://doi.org/10.35293/jdd.v2i1.30

Decolonisation as a theory focuses on challenging the colonial and imperialist perspectives on Africa and Africans. It seeks to debunk hegemonic discourses on Africa by continually opposing and resisting those notions that cast Africans as primitive and backward (Hooks 2006). Law permeates all realms of social behaviour; law is also a tool of social engineering. It is also a truism that society needs law to solve the problem of social order by protecting certain human interests (Obilade 1991). Law in Africa has followed the standard and structure of the legal systems of the colonising powers (English, French, Spanish and Portuguese) to the detriment of indigenous laws; though some African countries, notably those that are English-speaking, have enacted legal pluralism in order to include customary law. The decolonisation thesis is to jettison all that is colonial in the legal system, and this idea may be laudable in principle. However, because Africa is bewildering in size with different cultures, language and political system, how will a decolonial curriculum be conceptualised? This paper therefore is an inquiry into conceptualising the law in African curricula by examining what decolonisation of law in Africa entails. It investigates the rationale for decolonising law and legal education, as well as the ideology and strategies needed to decolonise law in Africa. These considerations become necessary because they form a methodology against the insurgency of white hegemonic knowledge, which results in social and intellectual domination.

1 Senior Lecturer, Department of Jurisprudence \& International Law University of Lagos, Akoka Lagos Nigeria rige@unilag.edu.ng/asikia.whyte@gmail.com 


\section{Introduction}

The role of law - its function, features, and future - is of increasing significance in these changing, challenging times. The concept of law lies at the heart of our social and political life (Wacks 2015). Law is pervasive and there is hardly any area of human endeavour that law does not affect. The study of law therefore becomes particularly important not only because of the intellectual pursuit but much more because of the need to have a balanced legal education, as law serves as the foundation on which legal education stands.

Law has played an essential and continuous role in the dispossession and disenfranchisement of colonised people around the world. For example, in South Africa, Africans were denied access to land through law (Natives Land Act). Law was also the instrument used to dispossess the Aborigines of Australia, New Zealand and Canada of their native lands.

Law and its various institutions provided mechanisms for colonial, imperial and settler colonial programmes to be deployed, reinforced and sustained. What is made can, however, be unmade. Law has the potential to decolonise our communities and societies. There are recent and historical examples in which law has played a role in dismantling colonial and imperial structures instituted during colonisation. Nonetheless, the decolonial process is not complete and we have a long road ahead in undoing what law has managed to achieve. Legal education and training in Africa often follow the pattern established by the colonial powers: curricula are often a replica of what obtains in the imperial centre, regardless of the relevance of the syllabus to the African communities. For example, in English-speaking Africa, the law curriculum is patterned after the English Common Law system, while some allowance may be given to case laws from respective African states. However, the principles of law follow mainly those of English Common Law. Thus, the pedagogy is influenced by the rationale of the English legal system because the study of law and legal education emanates from the colonisation process in these African states.

Legal study is invariably a study of social order, the making of laws and their implementation; therefore, legal study must automatically be influenced by societal moralities which entail beliefs and practices dominant in the society. In most parts of Africa, the law and legal education do not reflect the societal morality; the disparity between law and lived realities of students in many parts of the developing world (and some parts of the developed world where indigenous peoples have been relegated) 
has led to the call for decolonisation of law curriculum in the university. It should be stated that with increasing awareness of the negative impact of western education on indigenous lives especially through law, scholars and students are beginning to query the relevance of the English legal system to everyday lives of Africans.

For example, the Council on Higher Education of South Africa (Speaking CHE) made a call for decolonisation in the following words:

The clarion call for decolonisation of the curriculum is a diverse one, not always based on similar concepts and ideologies when used by different individuals or groups. In some versions, the decolonisation of the curriculum is based on a broad understanding of curriculum which makes it necessarily bound up with a proposed decolonisation of the university - in other words, a fundamental change in the nature and identity of such institutions and a dismantling of the apparatus that is perceived to support and continue a colonial legacy, while in other versions 'curriculum' appears to be understood mainly as what is taught, requiring an Africanisation or indigenisation of the syllabus to become more relevant to a changing student population.

In Nigeria, there is also a call to depart from the English influence on legal education. For example, Ofori-Amankwa and Igweike among other observations notes that ' $[\mathrm{m}]$ any of the Law Faculties had been patterned after a foreign model, which had limited the outlook, contents, methods, research and continuing development of the institution' This observation by the learned professors is obvious as law and legal education have a colonial heritage. Law and legal education patterned after a foreign model will lead to crisis of not only law, but also legal education as pointed out by Chukwurah in 'Reflections on the crises in jurisprudence in Nigeria', in which he itemises the following (Chukwurah 1993):

a) Crisis of identity as to the nature of Nigerian law.

b) Crisis of language arising from the dominance of the English Language as the teaching medium for legal education and legal practice.

c) Crisis of legal education which naturally follows from the preceding crises; and

d) Crisis of justice about which Aguda warned that this country is wallowing in the mess of unequal justice, and we seem not to recognise the crises thus created (Aguda 1986). 
I cannot but agree with the jurist in his observations, and it seems apt to transpose his observation to the rest of Africa because law patterned after a foreign model will invariably lead to a crisis of identity, language, legal education and, of course, a crisis of justice. In considering the debates on decolonisation of the curriculum in higher education, my approach leans on the Africanisation of the law curriculum in Africa. My main examples come from Nigeria and South Africa. It also must be stated it is impossible to focus on all parts of Africa. It is in this vein that I consider an agenda for decolonising law in Africa and for conceptualising the curriculum. This article is an inquiry into an alternative law curriculum for law students in Africa.

This paper is divided into five parts. Part 1 serves as the introduction; Part 2 examines what decolonising law in Africa entails; Part 3 examines legal education in Africa; Part 4 discusses the rationale why law and legal education must be decolonised in Africa; and Part 5 looks at ways of conceptualising the law curriculum in Africa.

\section{Decolonising Law: What it is?}

Decolonisation (of law) asks for the critical inclusion of epistemologies, ways of knowing, lived experiences, texts and scholarly works that have been previously excluded from our disciplines. It asks us to think critically about the relationship between the location and the identity of writers, and the location and identity of their subjects (human or otherwise) (Adebisi 2018). Decolonisation is furthermore a move from a hegemonic or Eurocentric conception of law connected to legal cultures historically rooted in colonialism in Africa, toward a more inclusive legal culture (Himonga and Diallo 2017). Decolonisation is not limited to inclusion, as it seeks to overthrow those ideas and perspectives that devalue the 'other' in legal discourse. Thus, decolonising law entails a radical departure from the perspectives of received laws exported to Africa which have no link with African communities. Taking this position further, it seems Mafeje's (1991) view wherein he states 'to learn from African societies themselves - is to study them from "inside outwards" - as opposed to extracting facts' is what decolonisation entails. According to Gutto (2011), 'unless we decolonise our minds, it is going to be difficult to decolonise our law, legal system and justice system'.

Law often purports to be neutral but a closer look at law shows that it reflects the dominant perspective in a particular society. English Common Law is dominant in former British colonies in Africa and Asia and the Civil Law system practised in 
many former French Colonies reflects the perspectives of French society. This legal knowledge is rooted in the tenets of its society and does not draw on the precedents of African societies. The colonial authorities did not believe that Africans had laws. For example, in the preface to The Nature of African Customary Law, Elias, has this to say:

This present work is to make a plea of change of heart and of attitude on the part of western jurists towards indigenous laws and customs of Africa. All too often one finds the majority of persons in the legal world of Europe and America entertain curious notions regarding African legal ideas and institutions, varying from the vague scepticisms of those who think there were no such things as laws in Africa before the advent of the Europeans to those, while admitting that there were such laws demand a wholesale eradication of what exists and the substitution therefore of imported European legal concepts. This narrow attitude stems from the approach which judges everything in terms of European standards and values and dismisses out of hand anything that does not conform to such patterns. (Elias 1962)

Elias (1962) further argues that current legal theory has yet to take full account of African interpretations of the juridical problems with which law must grapple in each society. An intellectual adventure into African legal conceptions should enlarge our horizons, if not enrich our knowledge of the function and purpose of law in the modern world (Elias 1962).

Elias's treatise is an appeal to western scholars to have a rethink on African customary law. In a different vein, Taiwo appeal is to African scholars and intellectuals.

Every time African scholars are forced into sterile but needed efforts to assert that we are or we think, the urgent tasks of identifying and explicating what we are or what we think remain undone or only partly undone, and the possibility of a genuine dialogue with other civilisations is aborted. The world, especially the western world, and we ourselves are worse for it. We must decry this unfortunate situation and lament an end is nowhere in sight. But we must not despair. We must continue, despite all odds, to struggle against the misrepresentation of our situation in western (that is European and North American) media, scholarship, politics, history and other areas. (Taiwo 2004) 
Elias's and Taiwo's theses depict the agony of many African scholars when addressing persistent negative beliefs about Africa. How then can African legal scholars decolonise law? To this, I now turn.

Since the invasion of the colonialists in Africa, African cultures have witnessed rapid change, albeit in a negative sense. However, African law has also resisted its total subjugation. Decolonising law in Africa will need to be approached and tackled in a systematic manner devoid of romanticisation but built on knowledge in and of the context of African peoples. What is this knowledge and how can it be employed?

Knowledge is defined as '[u]understanding of or information about a subject which has been obtained by experience or study; and which is either in a person's mind or possessed by a group generally' (Cambridge 1996). For our purpose, the knowledge in question is law according to Africans, which should be obtained and possessed by would-be-lawyers of African descent. In promoting this knowledge, emphasis must be placed on the diversity of African peoples and cultures, which would show that the law teacher is knowledgeable in the legal affairs of African people. In proposing a new curriculum for a decolonised law in Africa, it is pertinent to examine the researcher i.e., the African intellectual, the ideology construct and the teaching.

\subsubsection{The African Intellectual}

The training of most law graduates in Africa is patterned after the colonial curriculum which depicts the law and tradition of the colonisers as the best model for any society. In Nigeria, for example, there is the Repugnancy Doctrine Test which is applied to many local traditions. The application of the repugnancy doctrine often leads to the striking down of those cultures which do not pass the repugnancy test. This form of education imbibed by students not only belittles the African tradition, but it also ensures that African ways of life are disparaged. To be able to reverse this trend, there must be a re-orientation of African intellectuals through production of knowledge. Doing so will counter Eurocentrism of knowledge and afford African students the impetus to bring change to knowledge by relating law to African experience and societal needs. Transformation of the law curriculum is needed to affirm Africa's awareness and cultural values which will serve as catalyst for African consciousness, emancipation and the ability to solve both societal and legal problems. 


\subsubsection{The Ideology Construct}

Law in most western countries is taught through the prism of conservatism, even while there are many schools of thought such as natural law, legal positivism, Marxism, critical legal theory, feminist theory and postmodernism. However, the dominant ideology taught in Anglo-Saxon law schools is conservatism. It is also this dominant school that is replicated in Africa. For law to be decolonised in Africa, a praxis of ideology must be embraced. Embracing a new ideology means forging a new category of thought and a new construction of subjectivity; it requires the creation of a new mode of thinking and of appreciating Africa and her way(s) of life. The question is, what ideology should be embraced? It is critical to state at this point that no intellectual teaches in a vacuum; it will be necessary to examine three main theories which are germane to our discourse.

- Critical Race Theory: a study of enlightenment concepts such as 'justice', 'truth' and 'reason'. These words reveal their complicity with power as it dissociates the law from the very social relations, especially racial and gender discrimination. Critical race theory argues that law reflects the reality of a privileged, elite, male, white majority. It is this culture, way of life, attitude and normative behaviour that combine to form the prevailing 'neutrality' of law (Wacks 2015).

- Postcolonial Theory: a study of the effects of colonialism on cultures and societies; it is concerned with how European powers conquered and controlled the 'other cultures and with the response of these groups to the conquest (Adebisi 2018).

- Subaltern studies: a study of how 'silent' voices are taking back their histories from elites and the Eurocentric bias of imperial history. A subaltern is a person pushed to the bottom of a hierarchy of class, caste, gender, language and culture (Adebisi 2018).

An examination of these three theories shows discontent with law and the status quo of knowledge, as it relates to minority groups. what it then means is the need to have a specific thought pattern in our quest for decolonisation of this law curriculum, as the present curriculum reflects the dominant structure and systemic imbalance of law and legal education in Africa. This imbalance needs to be addressed for legal 
education to have relevance not only to the student but also to society at large.

\subsubsection{Teaching and Research}

There may be a question as to whose knowledge our curriculum in Africa is based on, but the important question is: who is researching and who is teaching? The rote answer is the African must be the primary teacher and researcher in this enterprise. Not unmindful of the possibility of homogeneity and racial essentialism, Essop argues:

It is replacing white with black or Freud with Fanon and social conservatism with social radicalism which pits modernity against tradition. It calls for African solutions to African problems. But it does in a context where tradition is viewed as static rather than dynamic - evolving with changing social and economic contexts. (Essop 2016)

While I agree with the observation of Essop on decolonisation, I intend to adopt the arguments of Badat wherein he argues that:

It is clear curriculum relates to large and fundamental questions, and that the issue of decolonisation involves tackling simultaneously and concertedly the question and purpose of South African universities. It should also be clear that the curriculum is concerned with profound questions of values, epistemology, ontology and knowledge making and dissemination in a context of unequal social relations. (Badat 2017)

Badat's argument in this public lecture focus on universities in South Africa. It seems to me that this position holds sway in other African countries because invariably they all have suffered colonialism in varying dimensions and the need for decolonisation is paramount, especially as expressed in the words of Agrawal:

A commitment to decolonising processes evolved as a way of redressing colonial processes of knowledge generation and its implications of imperialism and knowledge/power relations. Decolonising the curriculum at the universities requires recognition of colonial hegemony and forms of domination within 
academic institutions. (Agrawal 2009)

\section{Legal Education in Africa}

The Europeans' arrival in Africa gave rise to formal legal education which produced legal professionals. The traditional West African culture, even without a formal law and legal education, attaches great importance to the learning of customary laws and practices in an informal life-long process. Traditional legal systems and customary laws in African poly-ethnic societies form 'part of a functioning, coherent and consistent totality' of the African way of life. Such legal practitioners include chiefs, elders and people with law-related responsibilities such as the tendana of the Dagaaba in Ghana (the tendana promulgates and administers law and order that affect cultural lives of the people). Many others were instrumental in establishing the rule of law by upholding societal values and helping in dispute resolution.

In most parts of Africa, local institutions providing legal education are only forty years old. Until the early 1960s, only a few African lawyers were trained in Britain. Due to years of neglect, there exists a dearth of legally qualified Africans. When local institutions were established, African countries typically faced an urgent need to train lawyers to run the courts and various government departments. Post-independence arrangements for legal education followed the pattern of colonial education in the respective states (Ndulo 2002).

Legal education is a major contributor to society in terms of the law profession and its personnel, the importance was stressed by Elias in 'Law in a Developing Society' (Owasanoye 2009; Elias 1975), where he proposed four distinct roles for law, namely:

- That laws should be a conscious means of economic development of the community and that they should accordingly ensure the orderly advance and social progress of the community.

- That law should aim at consciously improving the morals as well as the cultural tone of the community.

- That it should above all promote the various ethnic groups through deliberate discouragement of ethnic particularisms and ethnocentric prejudices; and

- That it should foster the growth of uniform laws. 
The dominant theory of legal education in Africa is taught under the influence of English and Roman-Dutch Common Law with its legal positivism approach which has no regard for anything African, though in some jurisdictions like Northern Nigeria, the influence of Islam is noted. This theory i.e., the legal positivist prepares future lawyers and judges to engage with western-type legal systems and legal cultures devoid of African legal thought or systems. Its mode of operation separates legal rules from a 'non-legal normative consideration of morality or political philosophy' (Himonga and Diallo).

This mode of study invariably impacts on the ability of a student to appreciate 'traditional' ways of knowing and seeing, as the student is acculturated to accept the western mode of reasoning as the norm and the only legitimate way. Legal education is conducted mainly in two places. The first in the university where the would-be lawyer spends between three to five years as students of foundational traditional law courses; the scope and content are prescribed by the relevant regulatory bodies (National Universities Commission). The second location is the various law schools where students are taught the rudiments of the practice of law separate from academic subjects.

It presupposes that legal education in Africa is given through the prism of legal positivism (a theory developed within a society whose ethos and ways have no correlation with Africa).

\section{Why Law and Legal Education must be decolonized?}

Decolonisation is a move from a hegemonic or Eurocentric conception of law connected to legal cultures historically rooted in colonialism in Africa to more inclusive legal cultures (Himonga and Diallo). The humanities have benefitted from decolonisation of knowledge, for example in history. The Ibadan School of History led by Kenneth Onwuka Dike, J.F. Ade Ajayi, and Obaro Ikime debunked the myth of Africans without history; they were able to publish texts that correct this negative perspective (Dike 1956; Ade Ajjayi 1966; Ikime 1980). In literature, many African authors such as Ngũgĩ, Wole Soyinka and Chinua Achebe demonstrated the prowess of Africans in literature (Ngugi 1964; Soyinka 1960; Achebe 1958). In the field of philosophy, Bodunrin, Gyekye, Wiredu, Mbiti and Oluwole were able to establish African philosophical thoughts (Bodunrin 1985; Oluwole 2000).

In the quest for decolonisation, law and legal education seems to be waking up 
to what scholars in humanities noticed more than five decades ago. It will be wrong to state that there has not been a need to address 'law as its is' in Africa, but the call has been slow in being heard. However, the call for decolonisation of the law curriculum has become very loud because of the failure of the received laws in many different parts of Africa; this is because there is a disconnect between the people and the laws which governs them. Some scholars have written on the need to decolonise the law curriculum. Murungi, for example, argues that, ' $\mathrm{t}$ ] o knows what it is to be an African lawyer necessarily entails to know what it is to be African and 'what is at stake in being African' (Murungi 2013).

Onazi's (2013) work on African legal theory explores certain questions that need to be addressed when examining African law. In this edited volume, scholars weigh on concepts such as African jurisprudence, African communitarianism and African philosophical knowledge (including scientific reasoning, analysis and deduction). It is necessary for scholars to clarify these concepts as their clarification serves as a framework in which legal values and postulates form the foundation of African legal theory and African jurisprudence (Onazi 2013).

Decolonisation of the law curriculum demands a shift from a western liberal hegemonic system of knowledge. Decolonisation moves beyond a critique of Eurocentrism to an interrogation of what 'African' and 'African law' entail. The decolonisation of legal knowledge in African universities therefore involves a critical recognition of the subjugation of Africa and, more importantly, of the challenges to the imperial knowledge foisted on Africans in the form of pedagogical strategies and research methodologies which do not recognise Africa's way of life and thinking. Furthermore, decolonising law in Africa recognises the active subjugation of African systems of knowledge by the colonialists and seeks to acknowledge the imperative of African knowledge and cultures in African legal systems.

Decolonisation does not make light of the project to decolonise because it is going to be messy and strained, yet it is committed to this work not only for the sake of it, but more importantly, decolonisation strength lies on synergies of culture, history and identity. Decolonisation of the curriculum therefore entails a reordering of knowledge towards the empowerment and emancipation of African laws.

\section{Conceptualising the Curriculum.}

Africa hosts a large diversity of ethnicities, cultures and languages and so in essence 
Africa is bewilderingly large. Mama paints a picture of African contexts thus:

We are aware that Africa has for centuries been afforded a special place in Western mythology, a dark and antithetical land of fables and fantasies, imbued with sexuality, violence and taboo. The advent of modern science did little to interrupt this fabulous status, but rather continued to construct the mother continent as a series of myths that grew more gothic with every generation, and which gained currency as underdevelopment gained ground. (Mama 2007)

\subsection{What will a decolonised curriculum entail?}

The Nigerian legal curriculum reflects the structure of western legal courses. For example, the standard law curriculum entails compulsory and elective courses which the students must pass in order to be awarded a Bachelor of Laws (LLB HONS). The courses are as follows: Constitutional Law, Law of Contract, Nigerian Legal System, Law of Torts, Legal Research Method, Law of Evidence, Equity and Trust, Land Law, Criminal Law, Jurisprudence and Legal Theory, Environmental Law, Conflict of Law, Administrative Law, Family Law and Succession, Public International Law, Labour Law, Law of Business Association, Law of Banking and Insurance, Revenue Law, Law of Commercial Transactions, Criminology and Long Essay. These subjects are offered within a four-year or five-year studentship. The Nigerian Universities Commission sets the benchmark for the curriculum applicable to all universities. Some of the courses are compulsories while others are electives.

In fashioning a curriculum, the context and content of the curriculum is important. The first question is: does Africa have a corollary of the listed courses? The answer depends on who is giving a reply to the question. It seems to me that Africa does not have a corollary of Law of Banking and Insurance, Trust Law and Criminology. However, it is possible to have a corollary to some of the subjects such as Constitutional Law though varied in Africa due to difference in political institution (s); in Law of Contract for example Africans have always engaged in trade with one another even though the legal tender may not be money; Law of Torts will certainly have a corollary in Africa, as tortious acts certainly exists; Legal Research methods in Africa law curriculum will depart from the present mode of knowledge to appreciate the African way of thinking; similarly in Law of Evidence students 
will learn to appreciate the African mode(s) of evidence which is an hybrid of both accusatorial and inquisitorial process.

Equity thus exists in Africa as a principle. While the definition of equity in Africa may not equate to that used of England or any European jurisdiction, African society places premium on equity as there are African maxims portraying equity, such as, it is a wicked elder that listens to one side of the story and gives judgement. For, Land Law (Africa certainly has its land tenure system and this is taught alongside colonial Land Law); Customary 'criminal law' in Africa is a departure from that of the common law system (as it emphasises mediation and conciliation) in its process. Jurisprudence and Legal Theory will have a corollary in African Jurisprudence, which invariably is living and in many ways guides action of majority of Africans while Environmental Law as a subject will resonate with law in Africa, because care for the environment is found in the preservation of forests and rivers in many African societies. Conflict of Law invariably does have a space as conflict exists in all societies; Africa has always devised a way of resolving disputes be it in marriage, family or business. Administrative Law (Africans are strong in administration of political institutions within their respective domains); Family Law and Succession-the core of law in Africa revolves around family and succession; and Public International Law-it is wrong to assume Africans do not have contact with each other prior to the colonialists; (of course, in those times, the different peoples related to one another without recourse to 'state'); Labour Law-labour relations form part of African ethos (communal ownership of the means of production entails control over labour and decision making power for both male and female (Steady 1996). Law of Business Association (Company Law) and the idea of Companies is an offshoot of colonialism (while families may engage in a particular trade, the venture(s) do not follow the pattern of company law); Revenue Law-while Kings, Chiefs exact tolls from their subjects it cannot be compared to present day revenue drive in most African states in form of taxation.

Historical sources show that women were not paying taxes in many parts of Africa before the advent of colonialism (Aba Women's War) Law of Commercial Transactions: while, both men and women engage in trading activities. However, the volume of trade and the manner of trade is not as elaborate as what obtains in modern times. Having examined the various law courses that are offered under the curriculum, it seems to me that in conceptualising a law curriculum with an agenda for decolonisation emphasis must be placed on the following subjects: 


\subsubsection{African Law Curriculum Benchmark}

As stated above, to fashion a law curriculum, there is the need to set a benchmark for the respective law schools.

Constitutional law with emphasis on (Political Institutions in Africa, and with focus on respective locations).

African Legal System (which will cover an overview of legal systems but with concentration on the location of the law school in Africa; it will also consider the question of Repugnancy Doctrine especially in English Africa).

Land Law and Family Law and Law of Succession (these subjects need to focus on general principles of African ways of life as it relates to land tenure system and family institutions and practices in the respective societies).

International Law (this should be taught with focus on intergroup relations in Africa pre- and post-independence and customary state practice).

Women and Children Law in Africa (will focus on both pre- and post-colonial status of both women and children, emerging issues in women and children law, women's rights and child rights).

Criminal Law, Labour Law, Law of Commercial Transactions (these should also place premium on pre- and post-colonial experiences and the emergence of the modern state/globalisation in criminal law, employment and labour issues and exchange of goods and services).

Environmental Law (the course will note the traditional form (s) of preservation of the environment, the new methods and emerging fields in the preservation of the environment); Revenue Law (African system of taxation which draws on land and production system of taxation)

Jurisprudence \& Legal Theory (a concentration on African ideas on concepts such as persons, rights, relevance of African law, relevant theories of African thoughts and obstacles to development of African Law).

Long Essay must be compulsory as this will test students' knowledge of law in African context.

\subsection{What Philosophical and Theoretical resources will be drawn upon?}

Philosophy is the study of the use of reason in understanding such things as the nature of reality and existence, the use and limits of knowledge and the principles 
that govern and influence moral judgement (Cambridge 1996).

Thus, in fashioning a decolonised law curriculum, the underlying philosophy for the law curriculum will be governed by African moral judgement, this is necessary because law reflects the society in which it operates in. This philosophy hinges on African perspectives which draw upon the concept of 'ultimate value.' According to Agrawal,

The notion of ultimate value serves as the regulative principle for the determination of moral values and in certain cases it may serve to disqualify an accepted value as a moral value. Moral reasoning is distinct from moral practice; it is a self-conscious activity. As such it is definite in purpose. (Agrawal 1985)

The philosophy of the law curriculum in Africa will automatically lean on the principle of moral reasoning as distinct from moral practice; this dichotomy promotes self-analysis and self-consciousness. The other leg of the curriculum is theory, the Cambridge English Dictionary defines theory as: 1) a formal statement of the rules on which a subject of study is based or ideas that are suggested to explain a fact or more generally, an opinion or explanation (Cambridge 1996). A quick examination of this definition brings to fore certain rules and ideas in which a subject is based. Thus, in making a proposition for a curriculum, what will be of paramount benefit are the rules and ideas that originate in African-centred decolonial paradigm. As Dastile argues, 'because Africa and African subjects remain a contested terrain that has endured numerous forms of misrepresentation, intellectual and ideological terrains can no longer be imported from the west' (Dastile 2013: 93).

Part 2 above was a discussion of the various theories, namely critical race theory, postcolonialism and subaltern studies, which are useful in decolonising law in Africa. It seems to me that what is needed is an amalgamation of the three theories in the teaching and researching of law in Africa. However, there is also the need for an interdisciplinary approach, for law does not exist in a vacuum, it operates within a society. Interdisciplinarity is necessary because no single discipline can possibly address all the issues embedded in decolonisation. 


\subsection{What will the nature of a decolonised curriculum entail?}

The decolonisation of a law curriculum in Africa is a political and ideological venture; it is not an attempt to romanticise Africa, but it is a project of reclamation of identity and a generational debt to African children living and yet unborn for them to have a proper knowledge not only of their person(s) but also their environment. African intellectuals must labour in mind and soul to reconstruct the past, interpret the present and map out visions for the future of law and legal education.

Macintyre puts it succinctly when he argues that:

My position as an African scholar born in a world that still bears features of colonisation and Western influence is that we need to proceed from a position of intellectual suspicion about values born out of the western enlightenment project. (Macintyre 2003)

I cannot but agree with this assertion as law and legal education are certainly features of western enlightenment project foisted on Africa and Africans in a bid to bring about 'civilisation' of Africans. The nature of the curriculum will be grounded on sound epistemology and this in my view means taking a look at Mafeje's (2000: 68) approach which is 'building a theory from the ground up whose feature is Africacentred and "emotive" with exclusivist connotations. This approach is imperative because African legal scholars will have to take their objects of enquiry or units of analysis in their own terms in order to get across their message.

Second, there is need for deconstruction in decolonising the law project. Deconstruction entails a philosophical or critical method which argues that language, especially ideal concepts such as truth and justice is irreducibly complex, unstable or impossible to define (Encyclopaedia Britannica 2021). The use of deconstruction in decolonising law in Africa cannot be over-emphasised as it is the only avenue open to African legal scholars to correct age-old myths and fables about Africa. As Davidson argues:

Historically, in African discourse, Africa was represented as human preserve where the nature and condition of ancient man could be studied in simplicity and savage innocence; a reserve, moreover in which Negroes occupied the 
lowest place in the hierarchy of achievement. (Davidson 1964)

Deconstruction therefore becomes necessary as a tool in articulation of concepts, modes of knowledge production and a reclamation of voice in law and legal education in Africa.

Third, Afrikology is the process which enables African intellectuals to go beyond the normal limits of fragmented disciplinary regimes. It is a paradigm that aims to clarify and provide a starting point for an epistemology grounded in the lived experiences and realities of African people. It is a paradigm that 'seeks to build on the achievements of African people and the rest of humanity in order to emancipate themselves from the dehumanisation imposed by western civilisation' (Nabudere 2011). This position was affirmed by Leopold Senghor wherein he argues (1979) that "[I]f we want to build the "Homo Africanus" of tomorrow, we should once again assimilate without being assimilated. We should borrow from modernism only that which does not misinterpret our civilisation and our deep nature'. Senghor's (1979) appeal becomes especially important in decolonising the law curriculum in Africa simply because the study of law should be influenced by African traditions and take as a pattern the African philosophy of law designed to meet the needs of Africa (Meeting of Experts on African Charter on Human and Peoples' Rights).

\section{Conclusion}

In this paper, an attempt has been made to examine an agenda for decolonising law in Africa. In examining the need for decolonisation, I define what decolonisation is, what decolonisation of law entails and the reason why decolonisation of law is important. I stressed the importance of decolonising law and legal education curricula in Africa as indeed both political and deeply personal. This is because the decolonisation project strikes at the root of African legal personhood and culture. Further, I interrogate the present law curriculum and by extension propose an Africanised alternative. I conclude that decolonisation is a venture that is necessary because of the importance of knowledge and identity. 


\section{References}

Ade-Ajayi, J. (1966). Africa in the Nineteenth and Twentieth Century

Ade-Ajayi, J. (1971). History of West Africa, Volume 1 and 2.

Adebisi, F. (2018). Speaking of Decolonisation: Law, Race and the Legal Curriculum.

Paper presented at the Annual Conference of Socio-Legal Studies Association UK. Agrawal, A. (2009). Why indigenous knowledge?. Journal of Royal Society of Africa,

39 (4).

Agrawal, M.M. (1985). Moral and the Value of Human Life. In P. Bodunrin (ed), Philosophy in Africa: Trends and perspectives (pp. 207-226). Ile-Ife: University of Ife Press.

Aguda, T. (1986). The Crisis of Justice, Akure. Eresu Publishers.

Australia: The Native Title Act 1993

Badat, S. (2017). Trepidation, longing and belonging: Liberating the Curriculum at Universities in South Africa. University of Pretoria Public Lecture. 10 April.

Cambridge English Dictionary (1996)

Canada: Native Lands Act 1830

Chukwurah, O. (1993). Reflections on the Crises in Jurisprudence in Nigeria. In T. Elias and M. Jegede (eds), Nigerian Essays in Jurisprudence. Lagos: MIJ Publishers. Dastile, N. (2013). Africanus. 43(2): 93.

Davidson, B. (1964). The African Past: Chronicles from Antiquity to Modern Times. New York: The University Library Grosset and Dunlap.

Dike, K. (1956). Trade and Politics in the Niger Delta. Oxford: Oxford University Press.

Elias, T. (1962). The Nature of African Customary Law. Manchester: Manchester University Press.

Elias, T. (1975). Law in a Developing Society. Lagos: University of Lagos Nigeria.

Encyclopaedia Britannica retrieved 27 April 2021

Essop, A. (2016). Decolonising debate is a chance to rethink the role of the universities. The Conversation. 16 August.

Gutto, S. (2011). Decolonising the Law: Do we have a Choice? Paper presented at the International Conference on Decolonising our Universities, Penang, Malaysia. Himonga, C. and Diallo, F. (2017). Decolonisation and Teaching Law in Africa with special reference to Living Customary Law. PER/PELJ (20): 5.

Hooks, B. (2006). Postmodern Blackness. In S. Morgan (ed), The Feminist Reader 
(pp. 191-196). New York and London: Routledge.

Ikime, O. (1980). Groundwork of Nigerian History. Ibadan: Historical Society of Nigeria.

Ka'ai, T. (2005). Indigenising the Academy: Indigenous Scholars as agents of Change. Paper presented at the WIPE Conference Hamilton, New Zealand, University of Waikato.

Macintyre, A. (2003). After Virtue. Notre Dame: University of Notre Dame Press.

Mafeje, A. (1991). The Theory and ethnography of African Social Formations: the case of the Interlacustrine Kingdoms.

Mafeje, A. (2000). Africanity: a combative ontology. CODESRIA. 68

Mama, A. (2007). Critical Connections: Feminist Studies in African Contexts. In

A. Cornwall, E. Harrison and A. Whitehead (eds), Feminisms in Development: Contradictions, Contestations \& Challenges (pp.150.160). London: Zed Books.

Meeting of Experts for the preparation of the Draft Charter on Human and Peoples' Rights OAU Doc/CAB/LEG/67/3/rev

Murungi, J. (2013). An Introduction to Legal Philosophy. United Kingdom: Lexington Books

Nabudere, W. (2011). Afrikology, Philosophy and Wholeness: An Epistemology. Africa Book Collective.

Ndulo, M. (2002). Legal Education in Africa in the Era of Globalisation and Structural Adjustment. Penn State International Law Review, 20(3): 488-489

New Zealand: Maori Land Act 1993, Native Land Act 1862

Obilade, A. (1991). The Relevance of Customary Law to Modern Nigerian Society. In Y. Osinbajo and A. Kalu (eds), Towards a Restatement of Nigerian Customary Laws. Lagos: Federal Ministry of Justice.

Ofori-Amankwa, E. and Igweike, K. The Training of the Nigerian Barrister. Paper presented at the $18^{\text {th }}$ Annual Conference of the Nigerian Association of Law Teachers, Nigerian Law School, Lagos.

Oluwole, S. (2000). Africa. In A. Jaggar and I. Young (eds), A Companion to Feminist Philosophy (pp.96-107). Oxford: Blackwell Publishing.

Onazi, O. (2013). African Legal Theory and Contemporary Problems: Critical Essays. London: Springer.

Owasanoye, B. (2009). Legal Education and Legal Research: Issues and Challenges. In J. Fabunmi (ed), Themes on Jurisprudence \& International Law: Essays in Honour of Prof. M.A Ajomo (pp.327-338). Lagos: Total Communications Ventures. 
Senghor, L. (1979). Address to the Sixteenth Ordinary Session of the Assembly of Heads of Government, 17-20 July. Addis Ababa, Ethiopia.

Speaking CHE, Council of Higher Education Number 3 November (2017)2

Steady, F. (1996). The Black Woman Cross-Culturally. Rochester Vermont: Schenkman Books.

Taiwo, O. (2004). Feminism in Africa: Reflections on the Poverty of Theory. In O. Oyewumi (ed), African Women and Feminism: Reflecting on the Politics of Sisterhood (pp.45-66). Trenton: NJ Africa World Press, Inc.

Wacks, R. (2015). Understanding Jurisprudence: An Introduction to Legal Theory. Fifth Edition. Oxford: Oxford University Press. 